\title{
Viremia After One Month of Interferon Therapy Predicts Treatment Outcome in Patients With Chronic Hepatitis C
}

\author{
BEATRIZ GAVIER,* MIGUEL-ANGEL MARTÍNEZ-GONZÁLEZ, ${ }^{\dagger}$ JOSÉ-IGNACIO RIEZU-BOJ,* \\ JUAN-JOSÉ LASARTE,* NICOLAS GARCIA,* MARÍA-PILAR CIVEIRA,* and JESÚS PRIETO* \\ $*$ Department of Internal Medicine and Liver Unit and ${ }^{*}$ Department of Epidemiology and Public Health, Clinica Universitaria and Medical \\ School, University of Navarra, Pamplona, Spain
}

Background \& Aims: In chronic hepatitis C, interferon alfa induces sustained remission in less than $30 \%$ of treated patients. The aim of this study is to analyze viral status early after initiation interferon therapy as a predictor of treatment outcome. Methods: One hundred eighty-one patients with chronic hepatitis $C$ who had been treated with interferon alfa for 12 months (median follow-up, 49 months) were studied. Viremia and aminotransferase levels at the first and third months of therapy as well as 10 pretreatment variables were assessed as potential independent predictors of sustained response to treatment. Results: Sustained response occurred in 51 patients (28\%). At month 1 of treatment, viral persistence accurately predicted nonresponse (predictive value, 95.3; 95\% confidence interval, 86.0-98.8; $P<0.0001$ ). Independent predictors of sustained response were undetectable viremia at the first month of therapy $(P<0.001)$, undetectable viremia at the third month $(P<0.001)$, younger age $(P=0.006)$, nonsporadic infection $(P=0.012)$, and higher pretreatment aspartate aminotransferase levels $(P=0.032)$. In patients who cleared HCV RNA at month 1 of therapy, the predicted probability of sustained response averaged $70 \%$ for those younger than 30 years and diminished by $10 \%$ for each decade of age. Conclusions: Failure to clear HCV RNA at month 1 of treatment is strongly and independently associated with a very low probability of a sustained response to interferon.

$\mathbf{H}$ epatitis $\mathrm{C}$ virus (HCV) affects more than $1 \%$ of the world's population. ${ }^{1,2}$ Approximately $80 \%$ of acutely infected individuals develop chronic hepatitis, which often progresses to cirrhosis and not infrequently to hepatocellular carcinoma. ${ }^{3,4}$ Interferon (IFN)- $\alpha$ is currently the only effective therapy, but it needs to be administered for more than 6 months, and only a small percentage of treated patients have a long-term beneficial response. ${ }^{5,6}$ Although IFN has been in use for almost 10 years in the treatment of chronic hepatitis $C$, we still cannot make a clear recommendation as to who should be treated.
Factors that have been frequently demonstrated to influence the outcome of the therapy include age and duration of infection, ${ }^{7-9}$ absence of cirrhosis, ${ }^{10-12}$ body weight, ${ }^{12} \gamma$-glutamyl transpeptidase (GGTP) levels, ${ }^{12}$ viral genotype, ${ }^{13-20}$ and pretreatment serum titer of $\mathrm{HCV}$ RNA. ${ }^{13,16-22}$ However, pretreatment variables have not been useful to date in predicting the response to treatment in individual cases. ${ }^{23}$ Thus, to find more reliable parameters that might be useful in anticipating the results of the treatment, we have evaluated the predictive value of the elimination of viremia at 1 month into treatment in a large cohort of patients with chronic hepatitis $C$ followed up for more than 4 years. We have found that tracking the evolution of viremia early after starting IFN therapy is the best predictive factor for long-term outcome from this therapy. This parameter and patient age were used to build a logistic model to estimate the adjusted odds ratios (ORs) of a sustained response (SR) to IFN treatment.

\section{Patients and Methods}

One hundred eighty-one patients in whom chronic hepatitis $C$ had been diagnosed were included in the study. All patients had undergone a 1 -year course of IFN- $\alpha$ treatment in our center between 1988 and 1993. Before starting treatment, they had shown persistent ( $>6$-month) elevation of alanine aminotransferase (ALT) concentrations 1.5 times above the normal range, positive results of antibody to HCV testing (second-generation enzyme-linked immunosorbent assay) and HCV RNA testing in serum (polymerase chain reaction [PCR]), and histological evidence of chronic hepatitis with or without cirrhosis. Causes of chronic liver disease other than HCV were excluded. Patients with decompensated cirrhosis, systemic illness, or human immunodeficiency virus infection were also excluded. Availability of serial serum samples during

Abbreviations used in this paper: GGTP, $\gamma$-glutamyl transpeptidase; IFN, interferon; PCR, polymerase chain reaction; ROC, receiver operating characteristic; SR, sustained response.

(C) 1997 by the American Gastroenterological Association 0016-5085/97/\$3.00 
Table 1. Clinical, Biochemical, Histological, and Virological Features of 181 Patients With Chronic Hepatitis C Before Initiation of IFN- $\alpha$ Therapy

\begin{tabular}{lc}
\hline \multicolumn{1}{c}{ Characteristic } & Value \\
\hline Age $(y r)$ & \\
Mean & $44.08 \pm 14.4$ \\
Range & $18-71$ \\
Male sex, $\mathrm{n}(\%)$ & $128(70.7)$ \\
Body mass index $\left(\mathrm{kg} / \mathrm{m}^{2}\right)$ & $24.7 \pm 3.2$ \\
Source of infection, $\mathrm{n}(\%)$ & \\
Sporadic & $91(50.28)$ \\
Posttransfusional & $73(40.33)$ \\
Intravenous drug abusers & $17(9.39)$ \\
Serum ALT $(I U / L)$ & $139.63 \pm 99.51$ \\
Serum AST $(I U / L)$ & $70.94 \pm 49.6$ \\
GGTP $(I U / L)$ & $41.27 \pm 29.46$ \\
Liver histology, $\mathrm{n}(\%)$ & \\
Chronic hepatitis & $142(78.45)$ \\
Cirrhosis & $39(21.55)$ \\
Viral genotype, $\mathrm{n}(\%)$ & $116(64.08)$ \\
1b & $14(7.73)$ \\
1a & $6(3.32)$ \\
2 & $33(18.23)$ \\
3 & $3(1.66)$ \\
4 & $7(3.87)$ \\
Mixed infection & \\
Serum HCV RNA & $15.93 \pm 2.11$ \\
Logarithm copies $/ \mathrm{mL}$ & $585.06 \pm 180.2$ \\
Total dose of IFN $(M U)$ & $138(76.24)$ \\
Type of IFN given, $\mathrm{n}(\%)$ & $43(23.76)$ \\
Human lymphoblastoid IFN- $\alpha$ & \\
Recombinant IFN- $\alpha 2 \mathrm{~b}$ & \\
\hline
\end{tabular}

NOTE. Plus-minus values are means $\pm \mathrm{SD}$.

treatment and during the follow-up period was also required for inclusion. Patients were instructed to stop alcohol intake at least 6 months before starting treatment.

IFN ( 3 MU) was administered daily for 2,3 , or 4 months (to 128,25 , and 28 patients, respectively) and then three times a week (1.5-3 MU) for the following months until 1 year of therapy was completed in all cases. Table 1 shows the clinical, biochemical, histological, and virological characteristics of the patients.

\section{Follow-up During and After Therapy}

The median follow-up after completion of the treatment for all the patients was 49 months (range, 18-84 months). During the period of treatment, patients were followed up monthly with serial determinations of ALT concentration. Serum HCV RNA was tested in all patients before the start of treatment and at the end of 12 months of IFN therapy. HCV RNA was also determined in 132 patients at 1 month and in 137 patients at 3 months of therapy (both were determined in 101 patients).

During follow-up, ALT concentrations were determined every 3-6 months. HCV RNA was tested 1 year after the end of IFN therapy and at the end of follow-up in all patients. A variable number of additional HCV RNA determinations (one to seven) were also performed in each patient during followup.

\section{Response Criteria}

We considered a patient as having an SR when, after treatment, ALT levels remained within the normal range (1$22 \mathrm{IU} / \mathrm{L}$ in women and $1-29 \mathrm{IU} / \mathrm{L}$ in men) and serum HCV RNA was persistently negative during the whole follow-up period (minimum follow-up, 18 months). All other patients were considered as nonresponders.

\section{Determination and Quantification of HCV RNA and HCV Genotyping}

Serum HCV RNA was studied by reverse-transcription PCR as described previously. ${ }^{24}$ Two sets of primers specific for the 5' untranslated region of HCV genome (first PCR, 5'CCT GTG AGG AAC TAC TGT CT and 5'-CTA TCA GGC AGT ACC ACA AG; second PCR, 5'-ACT GTC TTC ACG CAG AAA GC and 5'-GAC CCA ACA CTA CTC GGC TA) were used. The limit of sensitivity of this assay was 1000 copies/mL. HCV RNA was quantitated in 74 pretreatment serum samples using a competitive PCR technique as reported previously. ${ }^{24} \mathrm{HCV}$ genotypes were determined following the method of Viazov et al. ${ }^{25}$ as described previously. ${ }^{24,26}$ For genotype 4 the probe $5^{\prime}-\mathrm{G}(\mathrm{A}, \mathrm{G}) \mathrm{C}$ CGT CTT GGG GCC $(\mathrm{A}, \mathrm{C}) \mathrm{AA}$ ATG AT was used.

\section{Statistical Analysis}

In the univariate comparison between those who actually presented SR and those who did not, 16 variables were analyzed: age, sex, body mass index (weight in kilograms divided by squared height in meters), source of infection (sporadic/nonsporadic), pretreatment ALT, aspartate aminotransferase (AST), and GGTP values, existence of cirrhosis, viral genotype, pretreatment viral load, type and total dose of IFN used, and serum HCV RNA and ALT levels at the end of the first and third months of treatment. Predictive values for SR or no response to IFN were calculated for HCV RNA test results and normal or raised ALT at the end of the first and third months of treatment.

The multivariable model (model A) was performed using the BMDP LR Dynamic software, and variables were selected using the purposeful method. ${ }^{27}$ Initial candidate variables were those with a $P$ value of $<0.25$ in the univariate analysis. A second model (model B) was built with the same criteria. In this model we included only those patients $(n=132)$ with an available serum HCV RNA determination at the end of the first month of treatment. A third model was developed to assess the predictive value of two variables (age and HCV RNA at the first month), which, having highly significant associations with the therapeutic response in the previous analyses, could be at the same time easily obtained in each patient. A receiver operating characteristic (ROC) plot was constructed with every cutoff point of the predicted probabilities, and the area under the curve was measured to assess the degree of 
discrimination provided by the model. ROC Curve Analyzer software (Centor and Keightley, Richmond, VA) was used to build the $95 \%$ confidence intervals (CIs) of the estimated areas under the ROC curve.

\section{Results}

Fifty-one (28\%) of the 181 patients with chronic hepatitis $C$ showed SR to therapy. The length of initial daily dosing of IFN had no influence on the response. The proportion of patients with SR was similar in those who had received 2,3 , or 4 months of initial daily IFN (31.25\%, 20\%, and $21.4 \%$, respectively; $P=0.36)$.

At 1 month into treatment, 68 of 132 tested patients had cleared HCV RNA from serum. Among these 68 patients, $34(50 \%)$ had SR and $34(50 \%)$ were nonresponders. On the other hand, among the 64 subjects who remained viremic at month 1 of therapy, 61 (95.3\%) were nonresponders, whereas only $3(4.68 \%)$ had SR. Thus, only 3 of the 37 patients with SR who were analyzed had detectable HCV RNA in serum after the first month of treatment; 2 of them became negative in the third month and 1 in the sixth month of therapy. There was a significant difference between patients with SR and nonresponders in the proportion of patients who had cleared HCV RNA after the first month: 34 of 37 patients with SR (92\%) and 34 of 95 nonresponders $(36 \%$; $P<0.001)$. At month 3 of therapy, 35 of 39 patients with SR $(89.7 \%)$ and 45 of 98 nonresponders $(45.9 \%)$ were HCV RNA negative $(P<0.001)$.

Transaminase levels measured at the first and third months after the start of therapy showed less significant association with the response. At 1 month into treatment, 61 patients $(34 \%)$ had normal ALT levels. Among these 61 patients, 25 (41\%) were patients with SR and 36 (59\%) were nonresponders. Among the 120 subjects who continued to have abnormal ALT levels after month 1 of therapy, $94(78 \%)$ were nonresponders, whereas 26 (22\%) had SR. There was a significant difference between patients with SR and nonresponders in the proportion of patients who had normalized ALT at the first month (25 of 51 [49\%] and 36 of 130 [28\%], respectively; $P$ $=0.01)$. This difference disappeared at month 3 of therapy (31 of 51 of patients with SR [61\%] and 60 of 130 of nonresponders [46\%] had normal ALT levels; $P=$ 0.08). Predictive values for SR or nonresponse according to AST and HCV RNA levels at the first and third month of treatment are shown in Table 2.

The univariate analysis of the clinical and virological characteristics showed the following variables to be significantly associated with a higher probability of SR (Table 3): younger age, lower body mass index, nonsporadic
Table 2. Predictive Values for HCV RNA and ALT at First and Third Months of Treatment

\begin{tabular}{lcc}
\hline & $\begin{array}{c}\text { Predictive value for } \\
\mathrm{SR}^{a}(95 \% \mathrm{Cl})\end{array}$ & $\begin{array}{c}\text { Predictive value for } \\
\text { no } \mathrm{SR}^{b}(95 \% \mathrm{Cl})\end{array}$ \\
\hline 1st month HCV RNA & $50.0(37.7-62.3)$ & $95.3(86.0-98.8)$ \\
3rd month HCV RNA & $43.8(32.8-55.3)$ & $93.0(82.2-97.7)$ \\
1st month ALT & $41.0(28.8-54.3)$ & $78.3(69.7-85.1)$ \\
3rd month ALT & $34.1(24.7-44.8)$ & $77.8(67.5-85.6)$ \\
\hline
\end{tabular}

aPredictive value for SR is calculated as the proportion of patients with negative HCV RNA (or normal ALT) who subsequently showed SR.

${ }^{b}$ Predictive value for no SR is calculated as the proportion of patients with positive HCV RNA (or raised ALT) who subsequently did not show SR.

source of infection, higher pretreatment levels of ALT, lower pretreatment levels of GGTP, absence of cirrhosis, genotype 3, clearance of serum HCV RNA at the first or third month of treatment, and (in a separate analysis of 74 patients in whom viral load was determined) lower pretreatment viral load $(P=0.04)$. Two other variables showed only a borderline association in the univariate analysis: higher pretreatment levels of AST $(P=0.06)$ and lower ALT values at month 3 of therapy $(P=0.06)$. We found no significant association between SR and sex, whole IFN dose, type of IFN administered, or ALT values at month 1 of treatment (considered as a continuous variable).

In the first multivariate logistic regression model (model A), which did not include HCV RNA (Table 3), five variables were shown to be significantly and independently associated with SR: younger age, nonsporadic source of infection, genotype 3, higher baseline levels of AST, and lower levels of GGTP. Cirrhosis showed a borderline association $(P=0.06)$ and was also included in this model.

In the second model (model B), involving 132 patients with available determination of HCV RNA at the end of the first month of treatment (Table 3), clearance of serum HCV RNA at month 1 into therapy was the strongest independent predictor of an SR. Other variables that remained independently associated with SR included lower age, nonsporadic transmission, and higher baseline levels of AST. When this second model was fully adjusted for the other eight variables, clearance of $\mathrm{HCV}$ viremia continued to be the most important predictor of SR (estimated OR, 12.8; 95\% CI, 3.16-51.9; $P<0.001$ ). In a separate multivariable analysis of 74 patients in whom viral load was quantitated, a lower pretreatment viral load also behaved as an independent predictor of an $\operatorname{SR}(P=0.03$; results not shown).

HCV RNA was studied at the end of the third month 
Table 3. Variables Associated With SR

\begin{tabular}{|c|c|c|c|c|c|c|}
\hline Variable & $\begin{array}{c}\text { Univariate analysis } \\
\text { OR }(95 \% \mathrm{Cl})\end{array}$ & $P^{a}$ & $\begin{array}{l}\text { Multivariate model A } \\
\qquad \begin{array}{c}(\mathrm{n}=181) \text { OR } \\
(95 \% \mathrm{Cl})\end{array}\end{array}$ & $P^{b}$ & $\begin{array}{l}\text { Multivariate model B } \\
\qquad(\mathrm{n}=132) \text { OR } \\
(95 \% \mathrm{Cl})\end{array}$ & $P^{b}$ \\
\hline Age (per year) & $\begin{array}{c}0.940 \\
(0.915-0.965)\end{array}$ & $<0.001$ & $\begin{array}{c}0.950 \\
(0.919-0.983)\end{array}$ & 0.002 & $\begin{array}{c}0.951 \\
(0.915-0.988)\end{array}$ & 0.006 \\
\hline Female sex & $\begin{array}{c}1.31 \\
(0.647-2.64)\end{array}$ & 0.36 & & 0.218 & & 0.643 \\
\hline $\begin{array}{l}\text { HCV-RNA- } \\
1 \text { st month }\end{array}$ & $\begin{array}{c}20.3 \\
(5.74-72.0)\end{array}$ & $<0.001$ & & & 19.5 & $<0.001$ \\
\hline HCV-RNA- & $\begin{array}{c}(0.74-1(2.0) \\
18.3\end{array}$ & $<0.001$ & NA & & $(4.94-77.2)$ & \\
\hline 3rd month & $(3.93-85.2)$ & & NA & & $N A^{c}$ & \\
\hline $\begin{array}{l}\text { ALT }(I U / L) \\
1 \text { st month }\end{array}$ & $\begin{array}{c}0.994 \\
(0.985-1.00)\end{array}$ & 0.15 & & 0.386 & & 0.607 \\
\hline $\begin{array}{l}\text { ALT }(I U / L) \\
\text { 3rd month }\end{array}$ & $\begin{array}{c}0.989 \\
(0.978-1.00)\end{array}$ & 0.06 & & 0.334 & & 0.878 \\
\hline $\mathrm{BMI}\left(\mathrm{kg} / \mathrm{m}^{2}\right)$ & $\begin{array}{c}0.857 \\
(0.766-0.959)\end{array}$ & 0.006 & & 0.422 & & 0.676 \\
\hline $\begin{array}{l}\text { Nonsporadic } \\
\text { transmission }\end{array}$ & $\begin{array}{c}2.732 \\
(1.38-5.41)\end{array}$ & 0.004 & $\begin{array}{c}2.85 \\
(1.17-6.90)\end{array}$ & 0.016 & $\begin{array}{c}3.53 \\
(1.27-9.90)\end{array}$ & 0.012 \\
\hline Genotype 3 & $\begin{array}{c}6.88 \\
(3.03-15.6)\end{array}$ & $<0.001$ & $\begin{array}{c}6.29 \\
(2.21-17.9)\end{array}$ & $<0.001$ & & 0.064 \\
\hline Cirrhosis & $\begin{array}{c}0.163 \\
(0.047-0.562)\end{array}$ & 0.001 & $\begin{array}{c}0.259 \\
(0.055-1.22)\end{array}$ & 0.063 & & 0.072 \\
\hline $\begin{array}{l}\text { Baseline AST } \\
(I U / L)\end{array}$ & $\begin{array}{c}1.01 \\
(1.00-1.01)\end{array}$ & 0.06 & $\begin{array}{c}1.02 \\
(1.01-1.03)\end{array}$ & $<0.001$ & $\begin{array}{c}1.01 \\
(1.00-1.02)\end{array}$ & 0.032 \\
\hline $\begin{array}{l}\text { Baseline ALT } \\
(I U / L)\end{array}$ & $\begin{array}{c}1.00 \\
(1.00-1.01)\end{array}$ & 0.002 & & 0.564 & & 0.280 \\
\hline $\begin{array}{l}\text { Baseline GGTP } \\
(I U / L)\end{array}$ & $\begin{array}{c}0.983 \\
(0.969-0.997)\end{array}$ & 0.02 & $\begin{array}{c}0.976 \\
(0.955-0.997)\end{array}$ & 0.012 & & 0.173 \\
\hline
\end{tabular}

NOTE. Multiple logistic regression analysis. Multivariate model A was performed with the 181 patients included in the study. HCV RNA was not considered because it was not available for all patients. Multivariate model B was performed with the 132 patients for whom HCV RNA at the first month of treatment was available. In the multivariate models A and B, ORs are shown only for those variables independently associated with SR.

OR, odds ratios (a higher OR corresponds to a higher likelihood of sustained response); CI, confidence interval; NA, not available; BMI, body mass index.

aUnivariate logistic regression, likelihood ratio test.

${ }^{b}$ Likelihood ratio test for every variable to be added to or removed from the presented model.

Viremia at the third month was analyzed in 137 patients, of whom 101 had also HCV RNA determinations done at first month. When these 101 cases were included in a multivariate analysis it was found that the magnitude of association with sustained response was similar to that of first-month HCV RNA clearance $(P<0.001)$.

of treatment in 137 patients, 101 of whom also underwent HCV RNA determination at the end of the first month. When viremia at month 1 and at month 3 were included in a multivariate analysis comprising these 101 patients (Table 3), we found that the magnitude of association with SR was similar for the two variables. Younger age, nonsporadic source of infection, and higher levels of AST retained their independent association with SR.

A model to assess the predictive value of the joint function of age and clearance of viremia at the end of the first month of treatment was developed with the 132 patients with available first-month viremia (mean age, 44.5; SD, 14.06; positive viremia at first month of treatment, $\mathrm{n}=64$; negative viremia at first month of treatment, $\mathrm{n}=68)$. The Hosmer-Lemeshow test indicated that this simpler model fit the data quite well $\left(\chi^{2}=\right.$
2.67; $d f, 8 ; P=0.96)$. The area under the ROC curve was 0.833 (95\% CI, 0.762-0.965; Figure 1), showing acceptable discriminating capabilities of the model. Accordingly, the information provided by the two variables would allow a correct classification of nearly $85 \%$ of the patients as patients with SR or nonresponders.

We calculated the absolute predicted probabilities of an SR for each combination of age and the serum HCV RNA status at the end of the first month of treatment. For a patient with negative viremia at the end of the first month of treatment, the predicted probability of long-term response averaged $50 \%$, with wide variability depending on age. The predicted probability reached $70 \%$ for a patient younger than 30 years old and diminished by about $10 \%$ for each decade of age, reaching a value of $20 \%$ for those patients older than 70 years (Fig- 


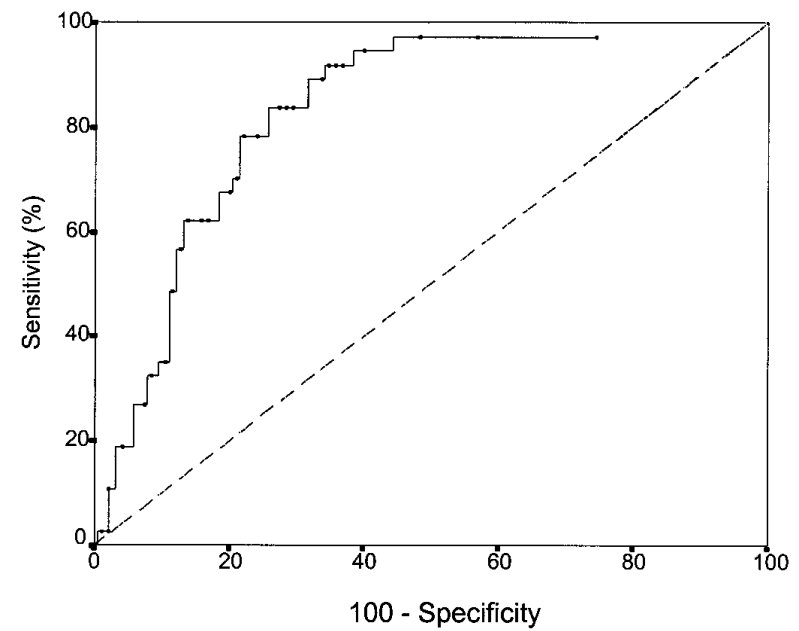

Figure 1. ROC curve for the logistic regression model using age and clearance of HCV RNA at 1 month into treatment as independent predictors. Sensitivity and 100-specificity (false-positive fraction) are computed for each possible value of the predicted probability by the model. The area under the ROC curve is 0.833 .

ure 2). On the other hand, if the viremia persisted positive after 1 month of treatment, the predicted probability of long-term response was very low (4.7\%; Figure 2).

\section{Discussion}

In our series of patients, pretreatment variables independently associated with a higher probability of SR to IFN were younger age, nonsporadic source of infection, higher AST levels, lower GGTP values, low viral load, HCV genotype 3, and absence of cirrhosis (the latter with borderline association). All these variables, except AST values, have been previously reported to be associated with long-term response. ${ }^{8,9,12-14,16,19,20,22,28}$ Among all the pretreatment parameters, age was found to be an important predictor. Duration of the disease could not be determined in a study like ours with a high percentage of sporadic cases. Although age could be a surrogate for duration of the disease, other studies ${ }^{8}$ have shown that younger age and shorter duration of the hepatitis were independently associated with SR to IFN. The importance of aging in the evolution of chronic hepatitis $\mathrm{C}$ has been highlighted by a recent study involving a great number of patients. ${ }^{29}$ It seems possible that weaker defense mechanisms against HCV determine poorer response to IFN with advancing age.

Although pretreatment variables could be useful to predict response to IFN in groups of patients, these data are of little help in isolated cases. ${ }^{23}$ To find more reliable parameters, we analyzed the evolution of viremia during the initial period of IFN therapy. We found that viral status at month 1 of therapy was the main independent predictor of the final outcome of the treatment. Previous studies $^{16,19,30}$ have shown that HCV RNA disappears promptly from serum (by the fourth week) in some of the patients undergoing the therapy. Orito et al. ${ }^{19}$ suggested that early HCV RNA clearance might be associated with long-term response to IFN. In these studies, however, the number of patients was limited, the followup was restricted to 6 months, and the criteria for SR were based solely on biochemical data. ${ }^{16,19}$ In the present study, involving patients followed up for more than 4 years, we found that disappearance of serum HCV RNA early after starting IFN was the best predictor of an SR as defined by both biochemical and virological data. However, the predictive value for an SR of HCV RNA clearance at month 1 of therapy averages only $50 \%$, with wide variability depending on the age of the patient ( $70 \%$ before 30 years of age and $20 \%$ after 70 years). In contrast to the limited predictive value of HCV RNA clearance, persistence of HCV RNA in serum at 1 month of treatment accurately predicted nonresponse (predictive value, $95.3 \%$ ).

Viral status at the end of the third month of therapy showed the same predictive value for SR and for no SR as the viremia at the end of the first month. These data indicate that predictions on treatment outcome based on viremia can be done as early as at the first month of therapy without risking accuracy. Thus, the present work provides evidence to support the importance of early determination of viremia during therapy and offers a reliable marker of nonresponse (persisting viremia after 1 month of treatment), which can be useful clinically.

Clearance of HCV RNA preceded normalization of serum transaminase levels. Compared with HCV RNA clearance, normalization of ALT at month 1 or at month 3 of therapy was found to be a poor predictor of the

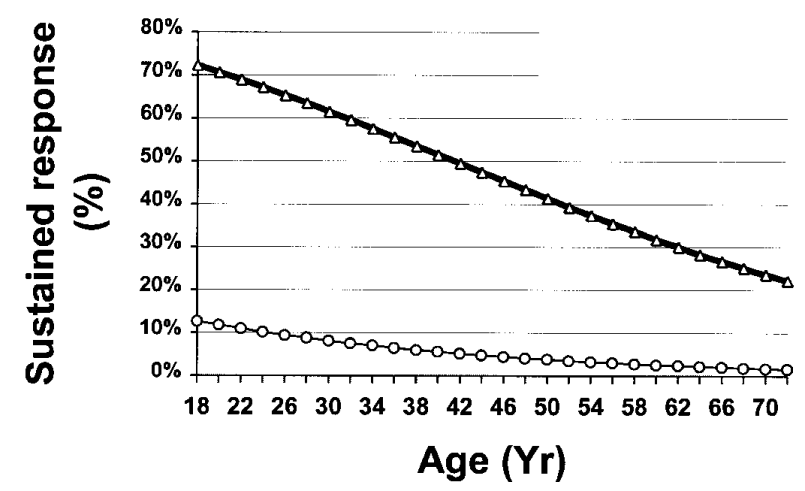

Figure 2. Percentage of patients with predicted long-term response to interferon ( $y$ axis) depending on age ( $x$ axis) and positive $(\bigcirc)$ or negative $(\triangle)$ serum HCV RNA determination (PCR) at month 1 of treatment. 
response to IFN (Table 2). Only after 6 months of treatment had transaminases acquired a statistically significant association with SR (predictive values, $45.8 \%$ for SR and $82.4 \%$ for no response; data not shown).

From our findings and other reports, it seems that IFN exerts its antiviral activities very shortly after initiation of the treatment. Thus, Chayama et al. ${ }^{31}$ reported $63 \%$ HCV RNA clearance after 2 weeks of 6 MU of daily IFN treatment. On the other hand, Zeuzem et al. ${ }^{32}$ showed a high turnover for $\mathrm{HCV}$, with a half-life of $\sim 2$ days. It is then conceivable that monitoring of serum HCV RNA during a period of time even shorter than 1 month could also be of value in predicting the response to IFN. Because there is a strong association between prompt elimination of viremia and response to IFN, it could be speculated that the best approach to eradicate HCV infection would be to attempt to rapidly reduce viral load by using higher doses of antiviral agents early at the beginning of the treatment.

Early monitoring of HCV RNA during IFN treatment may allow clinicians to obtain important information that could help them to adopt therapeutic decisions in individual cases. A model containing only age and determination of serum HCV RNA after receiving IFN for 1 month was developed because these two variables are easily obtained in each patient and because most of the predictive value of the model was retained with only these simple data. The improvement of the area under the ROC curve was only 0.057 when other predictors were also included. Some of these other potential predictors (such as HCV genotype and viral load) are not available to most laboratories. The inclusion of histology would require a liver biopsy, and exclusion of cirrhotic patients would negate treatment to some patients who could respond to the therapy. AST levels can easily change from one determination to another and therefore do not seem very useful for prognostic assessments. Therefore, the fitted model including age and viremia at month 1 of therapy seems the most appropriate on both a clinical and statistical basis. It should be considered, however, that, although the negative predictive value of this model is high, there is still a very small percentage of patients $(<5 \%)$ who could be misclassified as nonresponders, thus missing the advantage of the therapy. This small percentage should be balanced against the costs and adverse effects of the treatment.

In summary, the main finding of the present study is that when HCV RNA remains positive at month 1 of treatment, the probability of sustained response is very low, less than $5 \%$. On the other hand, when viremia becomes negative the probability of sustained response averages $50 \%$, varying from $70 \%$ to $20 \%$ depending on age. Although the validation of the model combining age and early virological response (Figure 2) needs confirmatory studies using external data and larger sample size, we can suggest the following recommendation: IFN may be given to any patient with diagnosis of chronic hepatitis $\mathrm{C}$, independent of his/her age, histological activity, genotype, or viral load. After 1 month of daily IFN administration, withdrawal of treatment or combination therapy should be considered in those patients who have not cleared HCV RNA. In this way, we can avoid unnecessarily prolonging the administration of IFN without excluding those cases who would otherwise experience a sustained response to the therapy. In selected patients, other treatment benefits (e.g., slower progression to cirrhosis, decreased risk of hepatocellular carcinoma) should also be taken into account before discontinuation of IFN.

\section{References}

1. Alter MJ. Epidemiology of hepatitis $C$ in the West. Semin Liver Dis 1995; 15:5-14.

2. Mansell CJ, Locarnini SA. Epidemiology of hepatitis $C$ in the East. Semin Liver Dis 1995;15:15-32.

3. Kiyosawa K, Sodeyama T, Tanaka E, Gibo Y, Yoshizawa K, Nakano Y, Furuta S, Akahane Y, Nishioka K, Purcell RH, Alter HJ. Interrelationship of blood transfusion, non-A, non-B hepatitis and hepatocellular carcinoma: analysis by detection of antibody to hepatitis C virus. Hepatology 1990;12:671-675.

4. Tong MJ, el Farra NS, Reikes AR, Co RL. Clinical outcomes after transfusion associated hepatitis C. N Engl J Med 1995;332: 1463-1466.

5. Shindo M, Di Bisceglie AM, Hoofnagle JH. Long term follow-up of patients with chronic hepatitis $C$ treated with alpha-interferon. Hepatology 1992;15:1013-1016.

6. Poynard T, Bedossa P, Chevallier M, Mathurin P, Lemonnier C, Trepo C, Couzigou P, Payen JL, Sajus M, Costa JM, Vidaud M, Chaput JC, and the Multicenter Study Group. A comparison of three interferon alfa- $2 b$ regimens for the long-term treatment of chronic non-A non-B hepatitis. Multicenter study group. N Engl J Med 1995;332:1457-1462.

7. Causse X, Godinot H, Chevallier M, Chossegros P, Zoulim F, Ouzan D, Heyraud JP, Fontanges T, Albrecht J, Meschievitz C, Trepo C. Comparison of 1 or $3 \mathrm{MU}$ of interferon alfa-2b and placebo in patients with chronic non-A, non-B hepatitis. Gastroenterology 1991;101:497-502.

8. Chemello L, Bonetti P, Cavalleto L, Talato F, Donadon V, Casarin P, Belussi F, Frezza M, Noventa F, Pontisso P, Benvegnu L, Casarin C, Alberti A, and the Triveneto Viral Hepatitis Group. Randomized trial comparing three different regimens of alpha-2ainterferon in chronic hepatitis C. Hepatology 1995;22:700-706.

9. Pagliaro L, Craxí A, Cammaá C, Tine F, Di Marco V, Lo lacono O, Almasio P. Interferon- $\alpha$ for chronic hepatitis C: an analysis of pretreatment clinical predictors of response. Hepatology 1994; 19:820-828.

10. Saracco G, Rosina F, Abate ML, Chiandussi L, Gallo V, Cerutti E, Di Napoli A, Solinas A, Deplano A, Tocco A, Cossu P, Chien D, Kuo G, Polito A, Weiner AJ, Houghton M, Verme G, Bonino F, Rizzetto M. Long-term follow-up of patients with chronic hepatitis $C$ treated with different doses of interferon- $\alpha 2 b$. Hepatology 1993;18:1300-1305. 
11. Alberti A, Chemello L, Bonetti P, Casarin C, Diodati G, Cavalletto D, Frezza M, Donada C, Belussi F, Casarin P, Pozzatto, Ruol A, and the TVVH Study Group. Treatment with interferon(s) of community-acquired chronic hepatitis and cirrhosis type C. J Hepatol 1993;17 (Suppl):S123-S126.

12. Camps J, Crisóstomo S, García-Granero M, Riezu-Boj Jl, Civeira MP, Prieto J. Prediction of the response of chronic hepatitis C to interferon alfa: a statistical analysis of pretreatment variables. Gut 1993;34:1714-1717.

13. Martinot-Peignoux M, Marcellin P, Pouteau M, Castelnau C, Boyer N, Poliquin M, Degott C, Descombes I, Le Breton V, Milotova V, Benhamou JP, Erlinger S. Pretreatment serum hepatitis $C$ virus RNA levels and hepatitis $C$ virus genotype are the main and independent prognostic factors of sustained response to interferon alfa therapy in chronic hepatitis C. Hepatology 1995;22: 1050-1056.

14. Hayashi J, Ohmiya M, Kishihara Y, Tani Y, Kinukawa N, Ikematsu $\mathrm{H}$, Kashiwagi S. A statistical analysis of predictive factors of response to human lymphoblastoid interferon in patients with chronic hepatitis C. Am J Gastroenterol 1994;89:2152-2156.

15. Tsubota A, Chayama K, Ikeda K, Yasuji A, Koida I, Saitoh S, Hashimoto M, Iwasaki S, Kobayashi M, Hiromitsu K. Factors predictive of response to interferon- $\alpha$ therapy in hepatitis $C$ virus infection. Hepatology 1994;19:1088-1094.

16. Marcellin P, Pouteau M, Martinot-Peignoux M, Degos F, Duchatelle V, Boyer N, Lemonnier C, Degott C, Erlinger S, Benhamou JP. Lack of benefit of escalating dosage of interferon alfa in patients with chronic hepatitis C. Gastroenterology 1995;109: $156-165$.

17. Aiyama T, Yoshioka K, Takayanagi M, Iwata K, Okumura A, Kakumu S. Serum HCV-RNA titer at the end of interferon therapy predicts the long-term outcome of treatment. J Hepatol 1995; 23:497-502.

18. Garson JA, Brillanti S, Whitby K, Foli M, Deaville R, Masci C, Miglioli M, Barbara L. Analysis of clinical and virological factors associated with response to alpha interferon therapy in chronic hepatitis C. J Med Virol 1995;45:348-353.

19. Orito E, Mizokami M, Suzuki K, Ohba K, Ohno T, Mori M, Hayashi $\mathrm{K}$, Kato K, lino S, Lau JY. Loss of serum HCV RNA at week 4 of interferon-alpha therapy is associated with more favorable longterm response in patients with chronic hepatitis C. J Med Virol 1995;46:109-115.

20. Kasahara A, Hayashi N, Hiramatsu N, Oshita M, Hagiwara H, Katayama K, Kato M, Masuzawa M, Yoshihara H, Kishida Y, Shimizu $Y$, Inoue A, Fusamoto H, Kamada T. Ability of prolonged interferon treatment to suppress relapse after cessation of therapy in patients with chronic hepatitis C: a multicenter randomized controlled trial. Hepatology 1995;21:291-297.

21. Yamada G, Takatani M, Kishi F, Takahashi M, Doi T, Tsuji T, Shin S, Tanno M, Urdea MS, Kolberg JA. Efficacy of interferon alfa therapy in chronic hepatitis $\mathrm{C}$ patients depends primarily on hepatitis C virus RNA level. Hepatology 1995;22:1351-1354.
22. Suzuki T, Tanaka E, Matsumoto A, Urushihara A, Sodeyama T. Usefulness of simple assays for serum concentration of hepatitis $C$ virus RNA and HCV genotype in predicting the response of patients with chronic hepatitis $\mathrm{C}$ to interferon alfa-2a therapy. J Med Virol 1995;46:162-168.

23. Conjeevaram HS, Everhart JE, Hoofnagle JH. Predictors of a sustained beneficial response to interferon alfa therapy in chronic hepatitis C. Hepatology 1995;22:1326-1329.

24. Larrea E, García N, Qian Ch, Civeira MP, Prieto J. Tumor necrosis factor alpha gene expression and the response to interferon in chronic hepatitis C. Hepatology 1996;23:210-217.

25. Viazov S, Zibert A, Ramakrishnan K, Widell A, Cavicchini A, Schreier E, Roggendorf M. Typing of HCV isolates by DNA enzyme immunoassay. J Virol Methods 1994;48:81-91.

26. Sarobe P, Jauregui JI, Lasarte JJ, García N, Civeira MP, BorrásCuesta F, Prieto J. Production of interleukin-2 in response to synthetic peptides from hepatitis C virus E1 protein in patients with chronic hepatitis $\mathrm{C}$ : relationship with the response to interferon treatment. J Hepatol 1996;25:1-9.

27. Hosmer DW, Lemeshow S. Applied logistic regression. New York: Wiley, 1989.

28. Rumi MG, Del Ninno E, Parravicini ML, Romeo R, Soffredini R, Donato MF, Zahm F, Colombo M. Long-term titrated recombinant interferon-alfa2a in chronic hepatitis $\mathrm{C}$ : a randomized controlled trial. J Viral Hepat 1995;2:73-76.

29. Poynard T, Bedossa P, Opolon P, for the OBSVIRC, CLINIVIR and DOSVIRC groups. Natural history of liver fibrosis progression in patients with chronic hepatitis C. Lancet 1997;349:825-832.

30. Kleter GE, Brollwer JT, Heijtink RA, Schalm SW, Quint WG. Detection of hepatitis $C$ virus RNA in patients with chronic hepatitis $C$ virus infection during and after therapy with alpha interferon. Antimicrob Agents Chemother 1993;37:595-597.

31. Chayama K, Arase Y, Koida I, Tsubota A, Saitoh S, Ikeda K, Matsumoto T, Kanda M, Iwasaki S, Kobayashi M, Hashimoto M, Unakami M, Morinaga T, Kumada H. Antiviral effect of lymphoblastoid interferon-alpha on hepatitis $C$ virus in patients with chronic hepatitis type C. J Gastroenterol Hepatol 1994;9:128133.

32. Zeuzem S, Schmidt JM, Lee JH, Rüster B, Roth K. Effect of interferon alfa on the dynamics of hepatitis $C$ virus turnover in vivo. Hepatology 1996;23:366-371.

Received December 3, 1996. Accepted July 15, 1997.

Address requests for reprints to: Jesús Prieto, M.D., Ph.D., Department of Internal Medicine and Liver Unit, University Clinic, Apartado 4209, 31008 Pamplona, Spain. Fax: (34) 48-296785.

Supported by grant 5395 by Gobierno de Navarra, by grant 940245 from Comision Interministerial de Ciencia y Technologia, Spain, and by J. Vidal and M. Mendez grants.

The authors thank Edurne Elizalde and Celia Asensio for technical assistance. 